\title{
Importance of Childhood Psychological Wellbeing on Parental Divorce-Educational Level Relationship
}

\author{
Anna Garriga $^{1}$ \& Jorge Martínez-Lucena ${ }^{2}$ \\ ${ }^{1}$ Universitat Pompeu Fabra \\ ${ }^{2}$ Universitat Abat Oliba-CEU \\ Correspondence: Anna Garriga Universitat Pompeu Fabra.
}

Received: December 11, 2017 Accepted: February 2, 2018 Online Published: April 23, 2018

doi:10.5539/res.v10n2p124 URL: https://doi.org/10.5539/res.v10n2p124

This article belongs to the project PROFAM ("Family as protection and the protection of the family") funded by Universitat Abat Oliba CEU and Fundació Bancària "la Caixa

\begin{abstract}
Although there is consistent evidence of the negative effects of parental divorce on children's educational level, the mechanisms and the protective factors that explain the consequences of divorce on children have not been clearly determined. This information is required in order to create effective policies and programs to help children through the divorce process. This study uses the longitudinal data from the British Birth Cohort Study 1970 and structural equation models to test whether family income, maternal supervision, and children's psychological problems mediate the effect of parental divorce on children's educational level and to what extent these variables are important protective factors for children through the divorce process. The main aim of this study, however, is to test the importance of children's psychological well-being on the relationship between parental divorce and children's educational level. Only two studies noted the importance of children's psychological well-being theoretically, but were unable to measure it. This study demonstrates empirically that children's psychological well-being is not a negligible mechanism and that this variable represents a very important protective factor for children of divorce, since the effect of psychological problems on educational level is significantly greater for children from divorced families than for those from intact ones. Although most family policies aimed at divorced families are targeted to improving family income, these findings reveal the need for governments to ensure that all children of divorce have access to programs and interventions designed to improve their psychological well-being.
\end{abstract}

Keywords: Parental divorce, children's psychological well-being, educational level, mechanisms and protective factors of divorce

\section{Introduction}

Over the last several decades, divorce rates have increased substantially in most western societies. Research shows that parental divorce is associated with several negative outcomes in children (Amato, 2010; Sigle-Rushton \& McLanahan, 2004). Prior to marriage dissolution, families who divorce differ from intact families in several characteristics, including parental conflict or socio-demographic background (Bhrolchain, 2001). Moreover, several studies designed to identify the causal effects of parental divorce concluded that there is consistent evidence of the negative effects of parental divorce on children's educational level (McLanahan, Tach, \& Schneider, 2013), which is a key determinant of individual life chances. These findings revealed the need to elucidate the mechanisms and the protective factors that explain the consequences of divorce on children in order to create effective policies and programs to help them through the divorce process.

Amato's divorce-stress-adjustment model notes that the effects of divorce largely depend on a set of mediators and moderators that children experience after their parents divorce (Amato, 2000). His model focuses on five main explanations: the loss of the non-custodial parent, the adjustment of the custodial parent, economic deprivation or disadvantage, inter-parental conflict and stressful life-changes. The scientific knowledge of the merits of these perspectives, however, is still limited, and the importance of other explanations, which are not included in this model, has been debated (Potter, 2010). In spite of this, most family policies and policy recommendations aimed at divorced families have largely been designed from the perspective of economic deprivation, since they mainly focus on improving family income (Breivik \& Olweus, 2006). The emphasis of policymakers on the income level of divorced families is not 
surprising. As Mayer (1997) pointed out, most social scientists consider income to be the most important influence on children. Indeed, some believe income is the only factor that matters. Moreover, as McLanahan and Sandefur (1994) argued, governments are in a better position to increase income than other types of more intangible family resources, such as the quality of parenting or children's emotional well-being. However, Breivik and Olweus (2006) stated, "quite a few social scientists and policy advocates are heavily influenced by economic perspective both in trying to explain why children of divorce have an increased risk of problematic outcomes and in suggesting ways to amend it". This perspective is based on an assumption that had not been clearly demonstrated in previous research, namely that family income is the most important factor in explaining the differences between children from divorced and intact families.

Although family policies pay little or no attention to other possible explanations, such as the quality of parenting, since the 1990s several scholars have shown that there has been a decline in parenting quality following parental divorce, and that this decline might explain some of the differences between intact families and divorced families (Elder Jr \& Russell, 1996; McLanahan \& Sandefur, 1994; Thomson, Hanson, \& McLanahan, 1994). Several programs aimed at increasing the quality of parenting by divorced parents have been developed and most show that improving the quality of parenting has a positive effects on long-term outcomes in children such as grades (for a review, see Vélez, Wolchick, \& Sandler, 2011). In spite of this, the literature places greater emphasis on studying family income than quality of parenting. However, more research on quality of parenting as mediator (Bastaits \& Mortelmans, 2016) and a protective factor in the divorce process is needed.

In addition, several studies have shown that the effect of parental divorce is stronger and more consistent on educational level than on test scores (Amato \& Keith, 1991; McLanahan, 1997; Sigle-Rushton, Hobcraft, \& Kiernan, 2005). For this reason, McLanahan (1997) suggested that something besides cognitive ability is responsible for the poorer school outcomes of children from non-intact families. Several studies have mentioned the importance of children's psychological well-being as a possible mechanism between parental divorce and children's educational level, although they were unable to measure it (Biblarz \& Raftery, 1999; Jonsson \& Gahler, 1997). They only speculated that, after controlling for other possible mechanisms, the net effect of parental divorce might be explained by the adverse psychological consequences of divorce. Potter (2010) empirically validated the link between parental divorce, children's psychological problems and test scores. No study has focused, however, on the relationship between parental divorce, children's psychological well-being and a long-term outcome such as educational level. To our knowledge, research has also not explored to what extent children's psychological well-being acts as a protective factor for the educational performance of children who experience parental divorce. The main reason for this lack of studies is that few surveys provide information both about children's psychological well-being before and after parental divorce and on long-term educational outcomes such as educational level. For this reason, more research on these issues is needed, since most programs for helping children of divorce are designed to address children's psychological well-being. Although they do not focus on working specifically on children's academic performance, they do, however, improve it (for a review, see Vélez et al., 2011).

Establishing whether family income, quality of parenting and children's psychological well-being explain the relationship between parental divorce and children's educational level requires the identification of three relationships: the relationship between these mediating variables and educational level, between parental divorce and the mediating variables, and between parental divorce and children's educational level. However, the various mediating variables posited are likely to be related. For this reason, to determine the contribution of a particular hypothesized mediating variable, it is also necessary to control for the impact of the other mediating variables and to take into account the indirect effects between them (Simons, Lin, Gordon, Conger, \& Lorenz, 1999). However, previous research has only investigated one or two mediating variables at a time. When proper controls were used, the effects reported for some explanations turned out to be spurious or indirect through other factors (Simons et al., 1999).

Divorce is often associated with a decline in material well-being. The economic resources of a household have to be divided in half, and each new house loses the advantage of economies of scale (McLanahan \& Sandefur, 1994). Research has shown that most women suffer a substantial loss of income after marital break-up, whereas men's economic circumstances appear to be relatively unaffected or can even improve slightly in some cases (Aassve, Betti, Mazzuco, \& Mencarini, 2007; Jarvis \& Jenkins, 1999; Mortelmans \& Jansen, 2010). Children also experience a substantial reduction in material well-being, since most of them live with their mothers after divorce. The negative association between parental divorce and children's educational achievement may, therefore, simply be a consequence of the economic hardship that often follows marital disruption. Mayer (1997) noted that income can affect children's outcomes in many ways. This decline in the standard of living may lead to a reduction of children's access to enrichment activities, such as tutoring, after-school classes or camp, and a decrease in their perception that their family can afford university. In fact, poorer families might not be able to afford university tuition or other costs of university, such as campus accommodation. Furthermore, limited means may lead a family to move to neighborhoods with inadequate schools (McLanahan \& Booth, 1989) that also limit access to higher education and improved economic results. 
In assessing the influence of family income, it is necessary to separate the effects of family income from the effects of the decline in the mother's quality of parenting, as well as those attributed to the level of involvement by a non-residential father or other family characteristics. To our knowledge, none of the previous studies that evaluate the importance of the mediating role of family income on the relationship between parental divorce and educational outcomes (Francesconi, Jenkins, \& Siedler, 2009; Jonsson \& Gahler, 1997; McLanahan \& Sandefur, 1994; Thomson et al., 1994) controlled for these other mediating variables, including quality of parenting. It is therefore possible that the effect of family income might be upwardly biased if these other mediating variables are not included in the analysis. Moreover, family income can have an indirect effect on the mother's parenting. Kiernan and Huerta (2008) showed that financial hardship often leads to maternal psychological distress and disrupted parenting practices in both single parent and intact families. The impact of reduced family income on the adjustment of children of divorce might therefore be expressed indirectly by its negative effect on the emotional well-being and the quality of parenting of the custodial parent (Simons et al., 1999).

Authoritative parenting is positively correlated with adolescent school performance, whereas authoritarian and permissive parenting are negatively so (Dornbusch, Ritter, Leiderman, Roberts, \& Fraleigh, 1987). Authoritative parents give warmth and support to their children but they also control and supervise them. Although a few studies have reported an association between family structure and the level of parental warmth and support, the dimension of parenting most consistently linked to the number of parents in the home is that of control and supervision (Simons et al., 1999). Divorced mothers control and supervise their children less than married mothers (Astone \& McLanahan, 1991; Bastaits \& Mortelmans, 2016; Simons \& Associates, 1996). Moreover, divorce is associated with a decline in the quantity and quality of the relationship between children and the non-custodial parent (Amato \& Gilbreth, 1999), usually the father, which means that the non-custodial parent has fewer opportunities to supervise the child. Bastaits and Mortelmans (2016) demonstrate that children who mostly reside with their mother after parental divorce receive less control from their father than children whose parents remain married.

Is the decline in quality of the parenting after parental divorce the reason for the lower educational attainment of the children of divorce? The evidence is mixed. Astone and McLanahan (1991) showed that differences in parental behavior account for only about 10 percent of the difference in dropout rates between children from single-parent and two-parent families. Similarly, Thomson et al. (1994) found that parenting practices account for virtually none of the differences in educational attainment between children from intact and non-intact families. Painter and Levine (2004) showed that parental involvement only explains a small part of the association between family structure and dropping out of high school. In contrast, Simons et al. (1999) found that the quality of mothers' parenting partly explains the relationship between divorce and conduct problems among adolescents. Moreover, McLanahan and Sandefur (1994) showed that parenting practices account for over half of the differences in high school dropout rates between children in single-parent families and those in two-parent families. Similarly, King and Sobolewski (2006) demonstrated that adolescents from divorced families are worse off in a range of outcomes when they have weak ties with both their mothers and non-resident fathers. Due to this lack of consensus, we believe it is important to focus more on this particular explanation for the effect of parental divorce on children's educational achievement.

Besides the decline in income and quality of parenting, as stated before, children's psychological adjustment might also explain some of the differences between children of divorced and intact families in regard to their educational attainment. Student achievement, such as test scores, has been linked to the state of children's emotional and mental health (Lane, Carter, Pierson, \& Glaeser, 2006; Needham, Crosnoe, \& Muller, 2004; Potter, 2010). Children with poor psychological adjustment are significantly less likely than others to graduate from high school and to enroll in postsecondary education (Kessler, Foster, Saunders, \& Stang, 1995; McLeod \& Fettes, 2007; Vitaro, Brendgen, Larose, \& Trembaly, 2005). These children have more disruptive behaviors at school, fewer academic aptitudes and educational expectations than children without psychological problems (McLeod \& Fettes, 2007). Additionally, abundant research shows that parental divorce has a negative effect on children's psychological well-being even when pre-divorce factors are considered and causal methods are used (for a review, see McLanahan et al., 2013). However, the pathways that explain the effect of parental divorce on this specific dimension of well-being are unclear, and more research is needed (Lacey, Bartley, Pikhart, Stafford, \& Cable, 2014).

A number of explanations have focused on the effect that divorce has on several aspects of a parent's well-being that, in turn, affect children's psychological well-being. As mentioned, parental divorce affects children's economic conditions and the quality of parenting and both factors are associated with children's psychological problems (Kiernan \& Huerta, 2008). Some studies showed that family income explains part of the effect of parental divorce on children's psychological well-being (Carlson \& Corcoran, 2001; Lacey et al., 2014; Morrison \& Cherlin, 1995; Thomson et al., 1994; Wu, Hou, \& Schimmele, 2008), while others indicated that this variable is not a mediating factor (Simons et al., 1999). Fewer studies have explored the mediating role of the quality of parenting on the relationship between parental divorce and psychological well-being (Bastaits \& Mortelmans, 2016). Simons, Whitbeck, Beaman, and Conger (1994) showed that 
among children from divorced families, the quality of the mother's parenting is associated with externalizing problems of boys and girls, and is also related to internalizing problems for boys. Bastaits and Mortelmans (2016) provided evidence that maternal and paternal parenting can mediate the relationship between post-divorce family structure and children's self-esteem and life satisfaction. By contrast, Thomson et al. (1994) showed that although quality of parenting explains part of the effect of growing up in a stepfather family on children's internalizing problems, this factor does not mediate the effect of growing up in a single mother family. Moreover, post-divorce conflict, non-residential father involvement and the mother's psychological well-being after divorce also affect children's emotional health (King \& Sobolewski, 2006; Simons et al., 1999).

Parental divorce might have a direct effect on children's emotional health regardless of family and parental characteristics and involvement. Pryor and Rodgers (2001) defined "trauma theories" as those theories that argue that parental divorce in itself has a negative impact on psychological outcomes, notwithstanding other family and parental characteristics and involvement. Feelings of loss and abandonment that children might experience after parental divorce could explain the decline of their emotional well-being after this event (Pryor \& Rodgers, 2001). In addition, another well-known argument is the so-called "attachment" theory (Bowlby, 1973, 1980), which stresses the fact that children have a need for a secure relationship with adult caregivers, without which normal social and emotional development might not occur. Parental divorce may lead to an insecure attachment by children to their parents (Waters, Merrick, Treboux, Crowell, \& Albersheim, 2000), which might explain the negative effect of parental divorce on children's psychological outcomes.

On the other hand, to what extent does family income, quality of parenting and children's psychological well-being have a greater protective effect against educational failure amongst children from divorced families than children from intact families? Very few studies have analyzed whether these variables influence each family type differently. Kiernan and Huerta (2008) suggested that quality of parenting has a stronger positive association with children's cognitive and psychological development among children from lone-parent families than among children than from intact families, although group differences are not significant. Xu, Zhang, and Xia (2008) found that the effect of parenting skills on children's academic performance and well-being is similar for children from two-parent families and those from divorced families. They also observe that among children from intact families, family income has a positive effect on children's academic performance and well-being, while among those from divorced families, this variable has a negative effect on academic performance and a non-significant effect on well-being. However, as mentioned, to our knowledge no study has explored to what extent children's psychological well-being is more important for the academic success of children in divorced families than it is for those in intact families.

Considering this background, this study has two main hypotheses, namely that: family income, maternal supervision, and children's psychological problems mediate the effect of parental divorce on a long-term outcome such as educational level and that these variables are important protective factors for children through the divorce process. In order to test these hypotheses, this study uses structural equation modeling, since this technique allows for the three mediating variables - family income, quality of parenting and children's psychological problems - to be taken into account in the same analysis, together with their indirect effects. With the exception of Havermans, Botterman, and Matthijs (2014), previous research on the explanations and protective factors of the divorce process on educational outcomes did not use this technique. Based on the theoretical and empirical evidence detailed above, the main aim of this study is to test the importance of children's psychological problems on the relationship between parental divorce and children's educational level. For this reason, this study uses the longitudinal cohort data from the British Birth Cohort Study 1970, which offers a unique opportunity to evaluate the importance of this variable since, to our knowledge, it is the only cohort survey that provides information about children's psychological problems during childhood, before and after parental divorce, as well as long-term outcomes. 


\section{Method}

\subsection{Participants}

The British Birth Cohort Study 1970 is a nationally representative, longitudinal study of a birth cohort in Great Britain. The BCS study follows the lives of a cohort of children born in one week of April in 1970. The original sample provides information on over 17,000 births. Later waves are similarly designed, and include a wide range of socio-economic, demographic, psychological, health, and attitudinal measures of the children and their parents (Despotidou \& Shepherd, 1998). With each successive wave, the scope of enquiry has broadened from a strictly medical focus at birth to encompass physical and educational development at the age of five, physical, educational and social development at the age of ten and then to include economic development and other factors at 30 years. Few longitudinal surveys are as multidisciplinary and long-term as the BCS. Compared with many other studies, the multidisciplinary character of the survey allows a range of factors to be taken into account that might explain the association between parental divorce and children's educational level, such as psychological well-being during childhood. It is important to highlight that there is a more recent UK cohort survey, the Millennium Cohort Study, that follows children born in 2000-01. This data has information about children's psychological well-being during childhood but does not yet have information about their educational level since these cohort children are still too young to have completed the higher educational levels. For all these reasons, we have used the British Birth Cohort Study 1970 in this paper.

We restrict the analyses to children whose parents remained together until the children were 21 years old (inclusive) and to children whose parents divorced or separated between wave 1 (age 5) and wave 2 (age 10). We do not distinguish between children whose parents were cohabitating and those whose parents were married, since including only those that were married could produce a bias in the analysis and, moreover, few children were living in a cohabiting family. We exclude children who were born in to a single-parent family at birth or whose parent(s) died or if they were living in foster care and those whose parents separated before age 5 or between 11 years and 21 years old. In order to create this sample, the information on family structure was collected at the waves when the children were 5, 10 and 30 years old.

\subsection{Procedure}

Due to data constraints, the analyses were limited to those children who experienced parental divorce between 5 and 10 years old and lived with the mother at this age, and those whose parents remained together until the children were 21. Firstly, relevant information on the controls and mediating variables was only available for the first and second BCS follow-up interviews at age 5 and 10. Sweep 0 , when the child was born, did not provide any information about the most important control variables needed and there was a large non-response rate to the third follow-up interview at age 16. Secondly, we only included in the analysis those children who lived with their mothers after divorce since, as mentioned in the introduction, custodial mothers and custodial fathers have different parenting styles (Hetherington \& Kelly, 2002; Simons \& Conger, 2007). We would have liked to have included children who lived with their father after the divorce in a separate analysis, but too few children had these living arrangements. The number of cases $(n=150)$ was not big enough to undertake the analysis when missing cases of meditating and control variables were taken into account. Furthermore, we restricted the sample to children whose parents remained together from birth until the age 21 (inclusive), since this age is around the time that most young people finish their university degree in the United Kingdom. However, we experimented with different cut-off points from 16 to 25 years old but found that there were no substantial changes in the results.

For the divorced group, we used the family structure variables from waves 1 and 2 . All longitudinal studies lose individuals between waves and the BCS is no exception. The target sample in the first wave (at age 5) was 16,181, 13,135 of whom were successfully interviewed, yielding a response rate of $78.9 \%$. Information on the family structure was available for all of them, and 11,752 (90.1\%) were living with both natural parents from birth to age 5. Of these, information was not available for 1,499 regarding their family structure at the second wave at age 10, mostly due to the fact that their families were not interviewed in this wave. Combining information for both waves, we find that 436 children experienced parental separation between the first and second waves, and were living with their mother by the second. Meanwhile, in order to create the group of children from intact families, we used information from the fifth wave, at age 30. The length of time between waves means that sample attrition is inevitable, particularly at older ages. In wave 5 (at age 30), out of a target sample of $15,503,10,833$ were successfully interviewed, which represents $70.4 \%$ of the target sample. 9,997 provided information about their family structure in childhood, with the parents of 7,531 of these cohort members having remained together from birth to age 21 . 


\subsection{Measures}

\subsubsection{Educational Level}

The main dependent variable is the highest level of academic or vocational qualifications attained by age 30 , as most people have obtained their final level of education by this age. When information on this variable was unavailable at age 30 (wave 5), we used information at age 26 (wave 4). The academic qualifications, in order of increasing attainment, were: the Certificate of Secondary Education (CSE) grades 2 to 5 (normally taken at the minimum school leaving age); the ordinary level General Certificate of Education (O level), normally taken at the minimum school leaving age; the advanced level General Certificate of Education (A level), normally taken at 18 years old; a degree or diploma (bachelor's degree or higher education diploma); and a higher degree (master's degree or doctorate). The vocational qualifications consist of National Vocational Qualifications (NVQs) and other vocationally-based credentials of an equivalent standard. NVQs are based on national occupational standards and are awarded for evidence of competency in work-based situations at 5 levels, reflecting increasing job complexity and personal responsibility. These academic and vocational qualifications are subsequently collapsed into 6 categories, reflecting increasing attainment: no qualifications; CSE grades 2 to 5/NVQ level 1 and equivalent; O levels/NVQ level 2 and equivalent; A levels/NVQ level 3 and equivalent; degree or diploma/NVQ level 4 and equivalent; and higher degree/NVQ level 5.

\subsubsection{Mediating Variables of Parental Divorce}

As mediating variables for the effect of parental divorce, this study used variables from the second wave when cohort members were 10 years old. We included variables that were related to each theoretical explanation exposed in introduction. Family income is not a continuous variable. Parents were asked about the range of family's gross weekly income: under 35 pounds per week; between 35 and 49 pounds per week; between 50 and 99 pounds per week; between 100 and 149 pounds per week; between 150 and 199 pounds per week; between 200 and 249 pounds per week; 250 pounds or more per week. In order to create a continuous variable of family income, we calculated the mean for each range but used 17.5 pounds for the lowest range and 275 pounds for the highest range. Although there are several ways of adjusting household income, recent OECD publications (e.g. Foster, 2009) use the square root scale. We therefore standardized this variable using the formula of pounds per week $/ \sqrt{ }$ number of people in the household. We found similar results using the OECD modified equivalence scale, which assigns a value of 1 for the head of the household, 0.5 to each additional adult member and 0.03 for each additional child.

We also created an index that measures maternal supervision, which is one dimension of quality of parenting that, as mentioned, has been consistently linked to family structure (Simons et al., 1999). Mothers were asked four questions referring to supervision: "Does your child go to the shops on his/her own? Does your child play in the street on his/her own? Does your child go to the park or playground on his/her own? Does your child go on local buses on his/her own?" For each question, the response options were: $1=$ almost every day; $2=$ about once a week; $3=$ seldom; $4=$ never. The index was calculated by adding up all answers. This variable has values ranging from 4 (minimum) to 16 (maximum). The alpha reliability coefficient for the four items in this study is 0.63 .

As stated in the introduction, the BCS70 allows children's psychological problems before and after parental separation to be taken into account. Children's psychological problems were measured on the Rutter Parental 'A' Scale of Behavior Disorder (Rutter, Tizard, \& Whitmore, 1970). This scale was completed by the parents - usually the mother- and was designed to measure behavior adjustment problems. However, only 15 items on the original scale were collected in wave 2. These items were summarized in a continuous variable, which takes values between 0 (no psychological problems) and 84 (highest psychological problems).

\subsubsection{Control Variables}

To estimate our complete models, we controlled for a variety of child and parental characteristics, all of which were measured in the first follow-up wave prior to any family disruption. Since the main dependent variable is the children's educational level at age 30, information on cognitive skills was obtained at age 5 from the English Picture Vocabulary test, which is an adaptation of the American Peabody Picture Vocabulary Test. It consists of a series of 56 sets of four different pictures, with a particular word associated with each set of four pictures. The child is asked to point out the one picture that corresponds to the given word and the test proceeds with words of increasing difficulty, until they make five mistakes in a run of eight consecutive items. The final item achieved is designated the ceiling item. The EPVT raw score is the total number of correct items occurring before the ceiling item. The resulting distribution of raw EPVT scores was skewed, and so the scores were transformed to give a standard normal distribution value $($ minimum $=-5$; maximum $=3)($ Institute of Child Health, University of Bristol, 1975).

Although the BCS70 dataset is rich in many domains, its ability to measure family processes, such as parental conflict, which is a very important control variable of the effect of parental divorce, is limited. There is no direct measure of family 
conflict. However, mother's mental health problems prior to divorce is related to parental conflict (Choi \& Marks, 2008). The mother's mental health was measured using the Malaise Inventory (Rutter et al., 1970). The Malaise Score is a continuous variable based on a 24-item questionnaire.

This study also included controls for each mediating variable explained above. Firstly, as for age 10, children's psychological problems at age 5 were measured using the "Rutter A Scale of Child Behavior Deviance Test", based on the mother's reports. At the first wave, a 19-item questionnaire was summarized in a continuous variable with values between 0 (no psychological problems) and 63 (highest psychological problems). Some items included in the original Rutter A-scale were excluded from this scale, mainly because of the high non-response rate to these items compared with the other items in the scale (Institute of Child Health, University of Bristol, 1975). It should be pointed out that the "psychological problems at age 5" variable has 19 items, while at age 10 this variable has 15 items. We therefore did not have exactly the same variable for children's psychological problems before parental divorce and afterwards, but they are broadly similar. Secondly, one of the main limitations of the British Birth Cohort Study 1970 is that the first wave contains no information about family income. For this reason, we used a proxy, namely the highest level of parental education completed by the father or the mother. This variable includes 6 categories: 1- No qualifications; 2- Low level vocational qualifications; 3- O-level or equivalent; 4- A-level or equivalent; 5- State Registered Nurse (SRN) or Certificated of Education (Teachers); 6- Degree. Thirdly, other control variables were related to quality of parenting before separation, such as "Father has read to the child in the last week" or "Mother has read to the child in the last week". The final control variable is sex, in which 1 is female and 0 is male.

\subsection{Data Analyses}

As mentioned earlier, this paper is based on the framework of structural equation modeling (SEM) and employs two types of structural equation models. A mediated structural equation model was used to disentangle the effect of parental divorce into direct and indirect effects, i.e. to observe the importance of family income, maternal supervision and children's psychological problems, in order to explain the effect of parental divorce on children's educational level. A multi-group model was also conducted in order to test whether the effects of family income, maternal supervision and children's psychological problems were statistically different for children from divorced families and for those from intact ones.

Structural equation models in this paper were estimated on the basis of a correlation matrix. Poly-choric and poly-serial correlations for non-continuous variables were used. These kinds of correlations provide better estimations of dichotomous and ordinal variables than Pearson correlations (Saris, van Wijk, \& Scherpenzeel, 1998). The PRELIS and LISREL programs enable data obtained from an ordinal scale to be analyzed by estimating a matrix of poly-choric and poly-serial correlations developed from categorical data and computing the asymptotic variance-covariance matrix for the estimation (Jöreskog \& Sörbom, 1996a, 1996b). For these reasons, the structural equation models in this study were undertaken using matrices of poly-choric and poly-serial correlations, and the asymptotic covariance matrix was estimated and used as input in the estimation of structural models. The analyses were carried out using the LISREL 8.51 computer program (Jöreskog \& Sörbom, 2001). Jöreskog and Sörbom (1986) recommend using the Weighted Least Squares Solution (WLS), rather than the Maximum Likelihood Solution (MLS). The former provides better estimates of the chi-square goodness-of-fit measures and standard errors for categorical and ordinal data than the latter. However, LISREL does not allow estimation of multi-group models using an asymptotic covariance matrix.

Meanwhile, assessing the correctness of a structural equation model is essential in avoiding incorrect conclusions from empirical research. In order to evaluate whether a model fits the data, we reported the chi-square test and the RMSEA. However, Saris, Satorra, and van der Veld (2009) showed that these fit indices do not provide sufficient evidence on the fit of models, because they ignore the power of the test. For this reason, the models were adjusted using JRule software for the detection of misspecifications (Van der Veld, Saris, \& Satorra, 2009) based on the procedure developed by Saris et al. (2009). If a misspecification was detected, we introduced the reasonable adjustments suggested by the JRule on a step-by-step basis.

In a longitudinal study, the potential for missing data to influence the results is very important. For this reason, two strategies were used to deal with missing cases (analyses of missing data available upon request). First, we carried out all analyses using list-wise deletion of missing data. This reduces the sample size by 37 percent. Although this method is the most common for dealing with missing data, it reduces statistical power and biases the parameter estimates. Secondly, we used multiple imputation estimation by using the PRELIS software. This procedure allowed all cases in the analysis (amounting to 7,967) to be included. Since the results of the methods for handling missing data were similar, the preferred model was the one with the largest sample size, which was obtained using the second strategy. 


\section{Results}

\subsection{Does Parental Divorce Have an Effect On Children's Educational Level?}

Table 1 shows the descriptive results for intact and divorced families for the different sets of variables measured at different points in time: the control variables measured before parental separation when the children were 5 years old; the mediating variables measured after parental separation when the children were 10 years old; and the children's educational level at age 30. Children from divorced families have a lower educational level than those from intact ones, and these differences are statistically significant. However, it is important to note that differences in educational achievement begin before parental divorce, since the vocabulary test score at 5 years old is lower for children who subsequently experience parental divorce than for those who do not. The descriptive results also show that before family dissolution, mothers that divorce have more psychological problems than those from intact families and that parents who experience this event are less educated and read less to their children than their counterparts in intact families; this is particularly true for fathers. These results indicate that the parents' disengagement starts before parental divorce. Before parental divorce, both groups of children, at age 5, have similar levels of psychological problems. Similarly, there are also important differences by family type in the mediating variables. After parental divorce, children from divorced families, at age 10, have more psychological problems and are less supervised than those from intact ones. Table 1 also shows that the divorced families only have around half of the income of intact ones. In short, families that divorce are different from those that stay together both before and after this event. For this reason, it is unclear from these findings alone whether the difference in children's educational level between children from intact and divorced families is due to parental divorce per se or to previous family characteristics.

Table 1. Means, percentages and standard deviations by family type.

\begin{tabular}{|c|c|c|c|c|}
\hline & Divorced families & Intact families & Total & \\
\hline \multicolumn{5}{|l|}{ Control variables } \\
\hline Gender & $45 \% * * *(\mathrm{std}=1.00)$ & $53 \% * * *(\mathrm{std}=1.00)$ & $53 \%$ & $(\mathrm{std}=1.00)$ \\
\hline Children's psychological problems at age 5 & $(\mathrm{std}=4.71)$ & $(\mathrm{std}=4.12)$ & 9.02 & $(\mathrm{std}=4.07)$ \\
\hline Mother's malaise at age 5 & $5.04 * * *(\mathrm{std}=3.74)$ & $3.99 * * *(\mathrm{std}=3.17)$ & 4.04 & $(\mathrm{std}=3.21)$ \\
\hline Mother having read to the child at age 5 & $68 \% * * *(\mathrm{std}=1.00)$ & $74 \% * * *(\mathrm{std}=1.00)$ & $73 \%$ & $(\mathrm{std}=5.69)$ \\
\hline Father having read to the child at age 5 & $39 \% * * *(\mathrm{std}=1.00)$ & $52 \% * * *(\mathrm{std}=1.00)$ & $50 \%$ & $(\mathrm{std}=5.69)$ \\
\hline Vocabulary test at age 5 & $-0.37 * * *(\mathrm{std}=1.32)$ & $-0.13 * * *(\mathrm{std}=1.28)$ & -0.15 & $(\mathrm{std}=1.28)$ \\
\hline Highest parental education & $2.50 * * *(\mathrm{std}=1.00)$ & $2.82 * * *(\mathrm{std}=2.46)$ & 2.56 & $(\mathrm{std}=2.46)$ \\
\hline \multicolumn{5}{|l|}{ Dependent variable } \\
\hline Educational level at age 30 & $2.09 * * *(\mathrm{std}=1.00)$ & $2.60 * * *(\operatorname{std}=1.00)$ & 2.58 & $(\mathrm{std}=2.89)$ \\
\hline \multicolumn{5}{|l|}{ Mediating variables } \\
\hline Children's psychological problems at age 10 & $25.70 * * *(\operatorname{std}=11.67)$ & $21.97 * * *(\operatorname{std}=10.19)$ & 22.17 & $(\mathrm{std}=10.30)$ \\
\hline Family income at age 10 & $38.98 * * *(\operatorname{std}=24.19)$ & $64.33 * * *(\operatorname{std}=27.34)$ & 62.93 & $(\mathrm{std}=27.74)$ \\
\hline Maternal supervision at age 10 & $8.96 * * *(\mathrm{std}=1.00)$ & $10.20 * * *(\mathrm{std}=1.00)$ & 10.01 & $(\mathrm{std}=1.98)$ \\
\hline
\end{tabular}

For means, independent samples t-test and $\chi^{2}$ test for percentages: $* \mathrm{p}<0.05, * * \mathrm{p}<0.01, * * * \mathrm{p}<0.001$.

Model 1 in Table 2 shows that parental divorce has a significant effect $(b=-0.18, p<0.001)$ on children's level of education. When control variables are included in Model 2, the effect of parental divorce decreases from -0.18 to -0.10 , a reduction of $40 \%$ of the impact but remaining significant ( $\mathrm{p}<0.001)$. It is important to note that the effect of other variables, such as parental education, on children's educational level $(b=0.38, p<0.001)$ is higher than the effect of parental divorce. These findings indicate that parental divorce is not the most critical factor determining educational achievement, but is a factor that has significant measurable consequences (Sandefur \& Wells, 1999). 
Table 2. Unstandardized coefficients from the structural equation models showing links between parental divorce and control variables on children's educational level.

\begin{tabular}{lll}
\hline & $\begin{array}{c}\text { Model }^{a} \\
\text { Educational level }\end{array}$ & $\begin{array}{l}\text { Model } 2^{b} \\
\text { Educational level }\end{array}$ \\
\hline Parental divorce & $-0.18^{* * *}(0.02)$ & $-0.10^{* * *}(0.02)$ \\
Sex & & $-0.04^{* *}(0.01)$ \\
Children's psychological problems & $-0.03^{* *}(0.01)$ \\
Mother's malaise & $-0.03^{* *} \quad(0.01)$ \\
Mother having read to the child in the last week & $0.02 \quad(0.02)$ \\
Father having read to the child in the last week & $0.16^{* * *(0.02)}$ \\
Highest parental education level & $0.38^{* * *}(0.01)$ \\
Vocabulary test age 5 & $0.10^{* * *}(0.01)$ \\
\hline
\end{tabular}

a $\chi^{2}=0.00$ d.f. $=1$, p-value $=1.00, \mathrm{CFI}=1, \mathrm{GFI}=1$, RMSEA $=.0000 . \mathrm{N}=7967$.

b $\chi^{2}=0.00$ d.f. $=21$, p-value $=1.00$, CFI $=1$, GFI $=1$, RMSEA $=.0000 . \mathrm{N}=7967$.

Standard Errors in brackets. ${ }^{*} \mathrm{p}<0.05, * * \mathrm{p}<0.01,{ }^{* * *} \mathrm{p}<0.001$ (two-tailed tests).

\subsection{Which Mechanisms are Relevant?}

One of the main goals of this paper is to analyze whether family income, maternal supervision and children's psychological problems after divorce explain part of the effect of parental divorce on children's educational level. Structural equation modeling allows us to test to what extent these variables mediate the effect between parental divorce and children's educational level. A mediating variable must be affected by parental divorce, and must also have an impact on children's educational level. Figures 1, 2 and 3 show the effect of parental divorce on each individual mediating variable and the direct effect of these variables on children's educational level. These models do not include the effects of the other mediating variables or the control variables.



Figures 1, 2 and 3. Mediated structural equation models for each mediating variable. Unstandardized coefficients are shown, with standard errors shown in brackets. ${ }^{*} \mathrm{p}<0.05,{ }^{* *} \mathrm{p}<0.01,{ }^{* * *} \mathrm{p}<0.001$. 
Figure 1 shows that the effect of parental divorce on family income $(b=-0.43, p<0.001)$ and the effect of this mediating variable on children's educational level $(b=0.30, p<0.001)$ are both large and significant. The direct effect of parental divorce on children's educational level decreases from $b=-0.18, p<0.001$ (see model 1 in Table 2 ) to $b=-0.05$ and is no longer significant once family income is included in the model. In the model without control variables, family income therefore mediates around $70 \%$ of the effect of parental divorce on children's educational level. Figure 2 shows that parental divorce has a strong and negative impact on maternal supervision $(b=-0.21, p<0.001)$ and that maternal supervision also affects children's educational level $(b=-0.15, p<0.001)$. Maternal supervision therefore mediates around $19 \%$ of the effect of parental divorce on children's educational level. Finally, Figure 3 shows that the effect of parental divorce on children's psychological problems is positive and significant $(b=0.16, p<0.001)$ and that these problems also have a significant impact on their educational level $(b=-0.13, p<0.001)$. Children's psychological problems consequently mediate around $13 \%$ of the effect of parental divorce on children's educational level. In summary, models without control variables demonstrate that the most important mediating variable is family income, but that maternal supervision and children's psychological problems explain a non-negligible part of the effect of parental divorce on educational level.

Figure 4 shows the links between parental divorce, income, maternal supervision, children's psychological problems after divorce and children's educational level, taking into account the control variables and the effects between the mediating variables. It also shows that although parental divorce has a significant effect on family income $(b=-0.37, p<0.001)$, family income does not have a significant impact on children's educational level $(b=0.02)$. Moreover, family income does not have a significant effect on children's psychological problems $(b=0.00)$ or maternal supervision $(b=-0.13)$ either. This mediating variable does not explain, therefore, the negative effect of parental divorce on educational level when the control variables are added. In contrast, the effect of parental divorce on children's psychological problems $(b=$ $0.07, \mathrm{p}<0.001)$ and the impact of this variable on children's educational level $(\mathrm{b}=-0.07, \mathrm{p}<0.001)$ are both significant. As a result, children's psychological problems explain around 5\% of the effect of parental divorce on children's educational level, which is small but not negligible. At the same time, maternal supervision also mediates around $15 \%$ of this effect, since parental divorce has a significant impact on maternal supervision $(b=-0.16, p<0.001)$, which has an effect on children's educational level $(b=0.09, \mathrm{p}<0.001)$. It can also clear that maternal supervision is not associated with children's psychological problems $(b=0.00)$. Finally, Figure 4 shows that the direct effect of parental divorce is still significant, which means that the mediating variables used do not explain the entire effect of parental divorce.

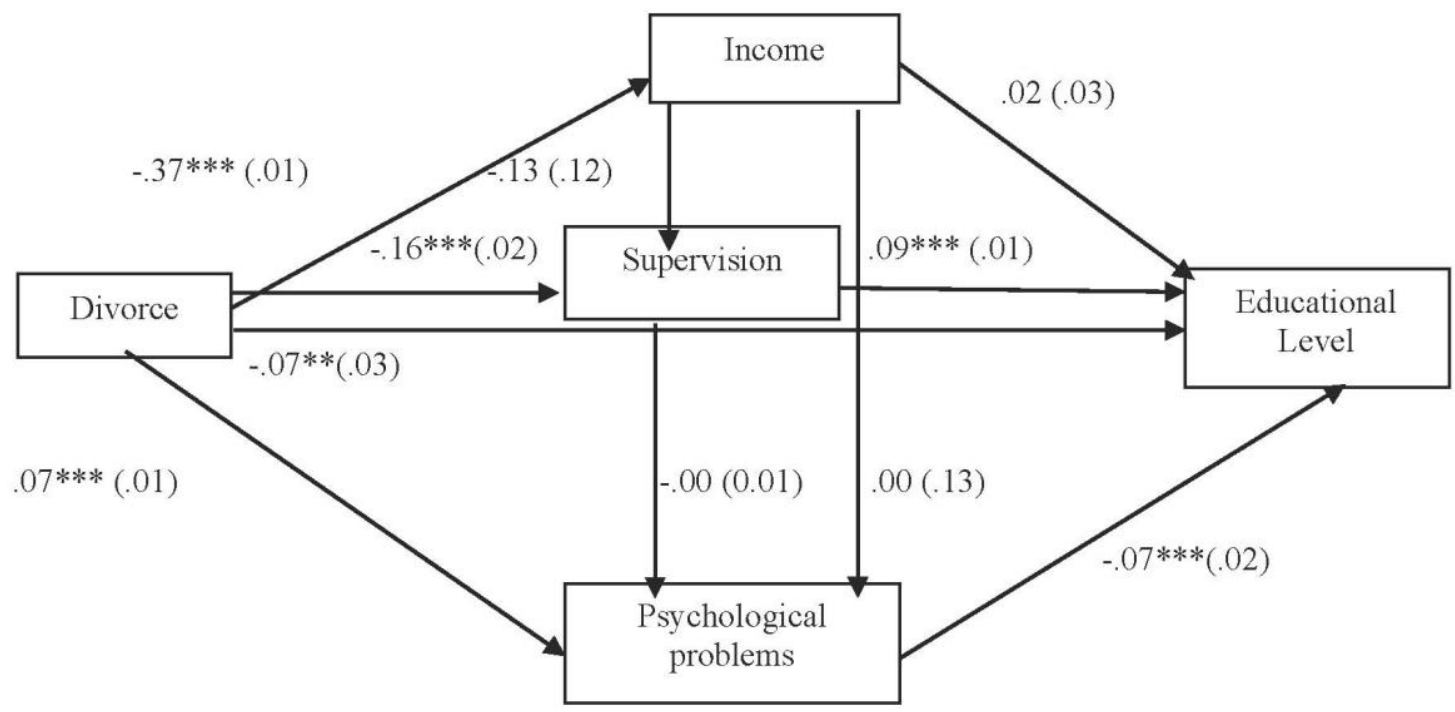

Figure 4. Mediated structural equation model considering all mediating variables. $\chi^{2}=10.90$ d.f. $=29$, p-value $=1.00$, $\mathrm{CFI}=1, \mathrm{GFI}=1, \mathrm{RMSEA}=.0000 . \mathrm{N}=7967$. Unstandardized coefficients are shown, with standard errors shown in brackets. 


\subsection{Do the Effects of Family Income, Quality of Parenting and Children's Psychological Well-Being Differ by Family Type?}

As mentioned above, the previous analyses are based on 7,531 children whose parents lived together until the cohort members were 21 years old, and 436 children whose parents divorced when they were aged between 5 and 10 years old. Due to the large difference in sample size between the groups, the effect of the mediating variables on children's education mainly reflects the effect of children from intact families. In other words, for children that have experienced parental divorce, the effect of family income, quality of parenting and children's psychological well-being on educational level might be different. To test this, we ran a multi-group comparison to see whether the effect of these mediating variables differed between children from divorced families and those from intact ones.

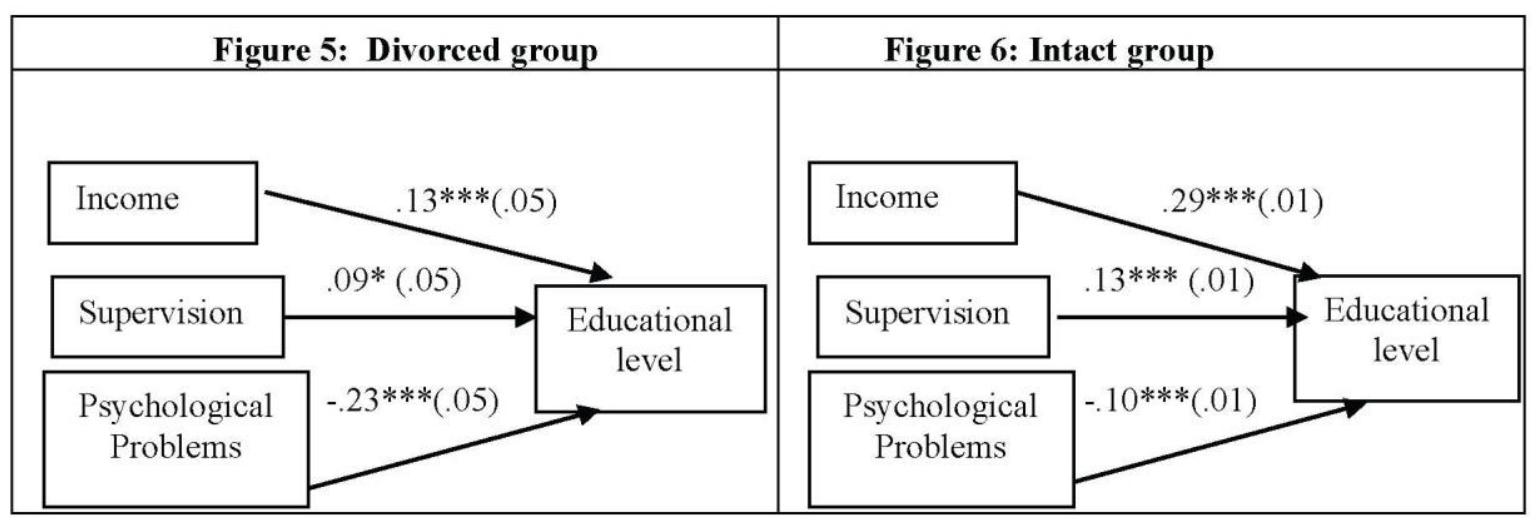

Figures 5 and 6. Multi-group structural equation model. $\chi^{2}=0.00$ d.f. $=12$, p-value $=1.00, \mathrm{CFI}=1, \mathrm{GFI}=1$, RMSEA $=.0000 . \mathrm{N}=436$ for the divorced group and $\mathrm{N}=7531$ for the intact group. Unstandardized coefficients are shown, with standard errors shown in brackets. There are several correlations between income, children's psychological problems and maternal supervision.

Figure 5 shows the effect of the mediating variables on children from divorced families, while Figure 6 shows these effects for children from intact families. Control variables and the indirect effects between the mediating variables are not included in these models. There are significant group differences for income $\left(\mathrm{x}^{2}=11.17, \mathrm{df}=1, \mathrm{p}<0.001\right)$ and psychological problems $\left(x^{2}=7.92, \mathrm{df}=1, \mathrm{p}<0.01\right)$. The impact of income on children's educational level is stronger for children from intact families $(b=0.29)$ than for children from divorced ones $(b=0.13)$. In contrast, the effect of children's psychological problems on educational level is lower for children that do not experience parental divorce $(b=-0.10)$ than for those that do $(b=-0.23)$. The path from maternal supervision to educational level is comparable for children from intact $(b=0.09)$ and divorced families $(b=0.13)\left(x^{2}=0.050, d f=1\right)$. However, it is unclear from this data whether these group differences remain when control variables are included in the model. 


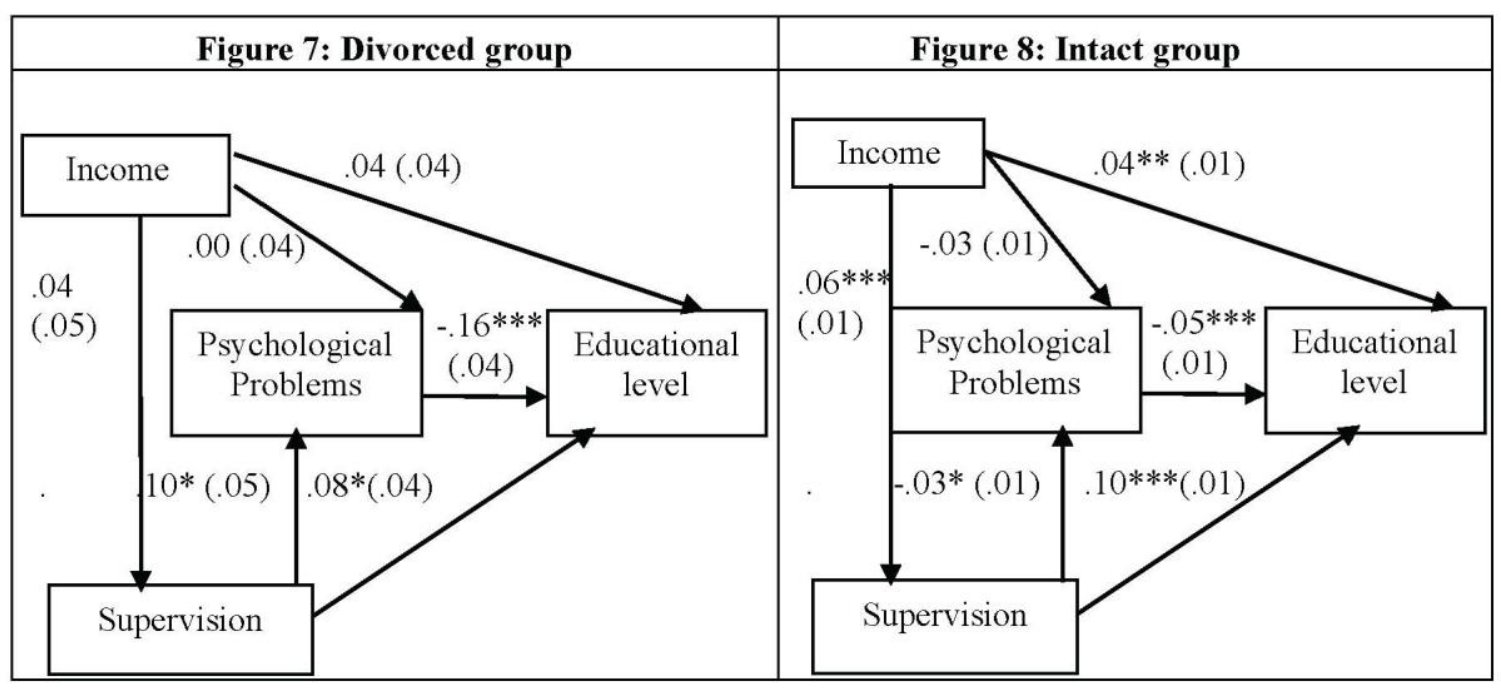

Figures 7 and 8. Multi-group structural equation model. $\chi^{2}=19.32$ d.f. $=29$, p-value $=1.00, \mathrm{CFI}=1, \mathrm{GFI}=1$, RMSEA $=.0000 . \mathrm{N}=436$ for the divorced group and $\mathrm{N}=7531$ for the intact group. Unstandardized coefficients are shown and standard errors are shown in brackets.

Figures 7 and 8 represent the coefficients of the mediating variables on children's educational level when control variables and indirect effects between the mediating variables are added to the model. Figure 7 shows the effect of the mediating variables for children of divorce only, and Figure 8 highlights this effect for children from intact families. A comparison of Figures 7 and 8 shows that the impact of children's psychological problems on their educational level is still higher and significantly different $\left(x^{2}=6.00, d f=1, p<0.05\right)$ for children from divorced families $(b=-0.16, p<0.001)$ than for those from intact ones $(b=-0.05, p<0.05)$. In contrast, when control variables are included, group differences in the link between family income and children's educational level are not significant $\left(\mathrm{x}^{2}=0.00, \mathrm{df}=1\right)$. This effect, however, is only significant for children from intact families $(b=0.04, p<0.01)$. Further examination of the data indicates that this difference is due to the different sample sizes of these two groups. When we performed a multi-group model in which we used the same sample size of intact group $(n=7531)$ for the divorced group $(n=7531)$, we found that the effect of family income on children's educational level for the divorced group was also significant $(b=0.04, p<0.01)$. Finally, the path from maternal supervision to children's educational level is similar for the divorced group $(b=0.08, p<0.05)$ and the intact group $(b=0.10, p<0.001)$. The inter-group differences in the link between maternal supervision and children's educational level are not significant $\left(\mathrm{x}^{2}=0.00, \mathrm{df}=1\right)$.

There are also some indirect effects among the mediating variables. Maternal supervision has a significant impact on children's psychological problems in both groups. For the intact group, the effect is negative $(b=-0.03, p<0.05)$, meaning that when children are supervised less, they have more psychological problems. For the divorced group, in contrast, the effect is positive $(b=0.10, p<0.05)$, indicating that for children from divorced families, more supervision is related to more psychological problems. This finding is unexpected, since as noted above, maternal supervision is positively related to children's educational level in both groups. Moreover, no group differences appear in the link between family income and maternal supervision. Although Figures 7 and 8 show that this parameter is significant only in the intact group $(b=$ $0.06, \mathrm{p}<0.001)$, it is also significant in the divorced group when the sample size of the divorced group is increased $(b=$ $0.04, \mathrm{p}<0.001)$. Furthermore, the effect of family income on children's psychological problems is not significant for either group.

\section{Discussion}

Although the literature on divorce strongly emphasizes an understanding of the mechanisms and protective factors of the divorce process, some limitations are still present. These limitations influence the type of policies and programs developed to help children through the divorce process. First, family income has received far more attention than the quality of parenting or other mechanisms. Second, most previous research on these mechanisms has only investigated them in isolation. Few studies have employed statistical techniques such as structural equations modeling, which allows the exact contribution of a mediator to be determined. Third, despite the well-established relationship between children's psychological well-being and educational outcomes, only one previous study has explored the mediating role of psychological well-being between parental divorce and children's educational outcomes (Potter, 2010). Four, only two studies have analyzed whether family income and quality of parenting have a greater protective effect on the educational 
success of children from divorced families than those from intact families (Kiernan \& Huerta, 2008; Xu et al., 2008). No study has evaluated the protective effect of children's psychological well-being. In this study, we have attempted to overcome these shortcomings by investigating the importance of these variables, measured at age 10, on the relationship between parental divorce and a long-term outcome, specifically, offspring's educational level, using structural equations modeling and the British Birth Cohort Study 1970.

The first goal of this study was to provide additional evidence to existing research on the mechanisms of the effect of parental divorce on children's educational level. Family income mediates this relationship in the models without the control variables as it has been shown to do in most previous studies. In fact, it is the most important mediating variable when compared with maternal supervision and psychological problems (Francesconi et al., 2009; Jonsson \& Gahler, 1997; McLanahan \& Sandefur, 1994). Contrary to previous research, when controlled by factors present in the family before parental divorce, family income is no longer a mediating variable, since it is not related to educational level despite continuing to be strongly link with parental divorce. This finding does not mean that family income is not an important factor in predicting the educational level of children from different family types, but that it is not a mediating variable of the effect of parental divorce. In addition, the structural equation models with and without control variables used in this study show that quality of parenting mediates a substantial part of the effect of parental divorce and that this mediating effect is independent from that of family income. These findings are important for two reasons: previous research showed mixed evidence about the mediating role of quality of parenting, and no study has evaluated the contribution of this mechanism while controlling for the effect of other mechanisms such as family income (Astone \& McLanahan, 1991; McLanahan \& Sandefur, 1994; Painter \& Levine, 2004). Finally, although the importance of children's psychological well-being as a mechanism of the effect of parental divorce on educational level has been recognized theoretically, this study is the first to demonstrate empirically that it is not a negligible mechanism. This result is also in accordance with that obtained by Potter (2010) for test scores.

The second goal of this study was to evaluate the protective effect of quality of parenting, family income and children's psychological well-being for the different family types. We found that the effect of quality of parenting on educational level is comparable for children from intact and divorced families. Xu et al. (2008) obtained similar results for children's academic achievement, while Kiernan and Huerta (2008) obtained different results for cognitive development of children at age 3. Despite the important differences on income level between children from intact and divorced families, we have shown that the effect of family income on educational level is greater for children from intact families than for those from divorced families when control variables are not included in the model, while in the model with control variables, there are no significant group differences. Xu et al. (2008) also obtained unanticipated findings, since they showed that family income is negatively related to the academic achievement of children from divorced families, while the opposite is true for those from intact families. Unlike previous studies, the results obtained here also demonstrate that children's psychological well-being is a very important protective factor for children of divorce. The effect of psychological problems on educational level is significantly higher for children from divorced families than for those from intact ones. In other words, in the former group, having psychological problems at age 10 leads to more long-term consequences than for the latter group. Additionally, in all models, the variable most determinant for the educational level of children from divorced families is psychological well-being, while this is not the case for those from intact families, since family income and quality of parenting are more important for this last group of children.

However, the findings of this study should be taken with caution due to its limitations. First, important information needed to determine the effect of parental divorce, such as parental conflict and family income before the event, was not available in the British Birth Cohort Study 1970. Second, this study has considered only one dimension of the measure of quality of parenting, in this case, parental supervision. However, other variables, such as parental support or quality of parent-child relationship, are also important (Bastaits \& Mortelmans, 2016). Third, information about the non-custodial parent, which is a very important mechanism and protective factor to be considered, was also missing in our data (Amato, 2010).

Despite these limitations, there are several policy implications of this study. Although, as mentioned above, most family policies and policy recommendations aimed at divorced families are targeted to improving family income (Breivik \& Olweus, 2006), our results suggest that, while income is important, it is not the only factor. Several programs and interventions for helping children from divorced families are designed to improve children's psychological well-being and quality of parenting and it has been demonstrated that they are effective in United States and Western countries such us Netherlands (Pedro-Carroll, 2011; Velderman, Pannebakker, van Vliet, \& Reijneveld, 2016; Vélez et al., 2011). However, in most countries, only a very small number of children benefit from these programs. Our findings confirm their importance and suggest that governments should ensure that all children who experience parental divorce can have access to them. For these reasons, taking into account the substantial increase in parental divorce in all western countries, universal access to these programs might not be only beneficial for children and families that experience this event but for society as a whole. 
Overall, the main contribution of the present study is that it provides additional evidence to that obtained by Potter (2010) regarding the importance of children's psychological well-being for educational outcomes of children of divorce. This finding gives support to the hypothesis of scholars (Emery, 1999; McLanahan, 1997) who suggest that poorer educational outcomes of children from divorced families are due to factors other than cognitive ability. In this respect, this study also extends the divorce-stress-adjustment perspective developed by Amato (2000), which does not include psychological well-being as a mediating effect or protective factor for children through the divorce process. Future research should continue to pay attention to Amato's (2010) advice on focusing less on mean differences between different family types and more on understanding the mechanisms and protective factors related to the divorce process. In this regard, Potter (2010) remarks that "consideration of the many factors involved in the divorce process will provide the best opportunity for continued growth in knowledge and understanding (p.944)".

\section{References}

Aassve, A., Betti, G., Mazzuco, S., \& Mencarini, L. (2007). Marital disruption and economic well-being: A comparative analysis. Journal of the Royal Statistical Society: Series A (Statistics in Society), 170, 781-799.

Amato, P. R. (2000). The consequences of divorce for adults and children. Journal of Marriage and Family, 62, 1269-1287.

Amato, P. R. (2010). Research on divorce: Continuing trends and new developments. Journal of Marriage and Family, 72, 650-666.

Amato, P. R., \& Gilbreth, J. G. (1999). Nonresident fathers and children's well-being: A meta-analysis. Journal of Marriage and Family, 61, 557-573.

Amato, P. R., \& Keith, B. (1991). Parental divorce and the well-being of children: A meta-analysis. Psychological Bulletin, 110, 26-46.

Astone, N. M., \& McLanahan, S. S. (1991). Family structure, parental practices and high school completion. American Sociological Review, 56, 309-320.

Bastaits, K., \& Mortelmans, D. (2016). Parenting as mediator between post-divorce family structure and children's well-being. Journal of Child and Family Studies, 25, 2178-2188.

Bhrolchain, M. N. (2001). 'Divorce Effects' and causality in the social sciences. European Sociological Review, 17, 33-57.

Biblarz, T. J., \& Raftery, A. E. (1999). Family structure, educational attainment, and socioeconomic success: Rethinking the "Pathology of Matriarchy". American Journal of Sociology, 105, 321-365.

Bowlby, J. (1973). Attachment and loss: Separation: Anxiety and anger. New York, NY: Basic Books.

Bowlby, J. (1980). Attachment and loss: Loss, sadness and depression. New York, NY: Basic Books.

Breivik, K., \& Olweus, D. A. N. (2006). Children of divorce in a Scandinavian welfare state: Are they less affected than US children? Scandinavian Journal of Psychology, 47, 61-74.

Carlson, M. J., \& Corcoran, M. E. (2001). Family structure and children's behavioral and cognitive outcomes. Journal of Marriage and Family, 63, 779-792.

Choi, H., \& Marks, N. F. (2008). Marital conflict, depressive symptoms, and functional impairment. Journal of Marriage and Family, 70, 377-390.

Despotidou, S., \& Shepherd, P. (1998). The 1970 British Cohort Study, twenty six year follow-up. London, UK: Social Statistics Research Unit, City University.

Dornbusch, S. M., Ritter, P. L., Leiderman, P. H., Roberts, D. F., \& Fraleigh, M. J. (1987). The relation of parenting style to adolescent school performance. Child Development, 58, 1244-1257.

Elder, G. H., \& Russell, S. T. (1996). Academic performance and future aspirations. In R. L. Simons (Ed.), Understanding differences between divorced and intact families: Stress, interaction, and child outcome (pp. 176-192). Thousand Oaks, CA: Sage Publications.

Emery, R. E. (1999). Marriage, divorce, and children's adjustment. Thousand Oaks, CA: Sage Publications.

Foster, M. (2009). What are equivalence scales. OECD Project on income distribution and poverty. Retrieved from https://www.oecd.org/eco/growth/OECD-Note-EquivalenceScales.pdf

Francesconi, M., Jenkins, S. P., \& Siedler, T. (2009). Childhood family structure and schooling outcomes: Evidence for Germany. Journal of Population Economics, 23, 1073-1103. 
Havermans, N., Botterman, S., \& Matthijs, K. (2014). Family resources as mediators in the relation between divorce and children's school engagement. Social Science Journal, 51, 564-579.

Hetherington, E. M., \& Kelly, J. (2002). For better or for worse. New York: Norton.

Institute of Child Health, University of Bristol. (1975). Guide to the BCS70 5-year follow-u. Retrieved from http://www.cls.ioe.ac.uk/library-media/documents/BCS70_userguide_age_5.pdf

Jarvis, S., \& Jenkins, S. P. (1999). Marital splits and income changes: Evidence from the British Household Panel Survey. Population Studies, 53, 237-254.

Jonsson, J. O., \& Gähler, M. (1997). Family dissolution, family reconstitution, and children's educational careers: Recent evidence for Sweden. Demography, 34, 277-293.

Jöreskog, K. G., \& Sörbom, D. (1986). LISREL VI: Analysis of linear structural relationships by maximum likelihood, instrumental variables, and least squares methods. Mooresville, IN: Scientific Software.

Jöreskog, K. G., \& Sörbom, D. (1996a). LISREL 8: User's reference guide. Chicago: Scientific Software International.

Jöreskog, K. G., \& Sörbom, D. (1996b). PRELIS 2 user's reference guide: A program for multivariate data screening and data summarization: A preprocessor for LISREL. Chicago: Scientific Software International.

Jöreskog, K., \& Sörbom, K. (2001). LISREL 8.50: User's reference guide. Chicago: Scientific Software International.

Kessler, R. C., Foster, C. L., Saunders, W. B., \& Stang, P. E. (1995). Social consequences of psychiatric disorders, I: Educational attainment. American Journal of Psychiatry, 152, 1026-1032.

Kiernan, K. E., \& Huerta, M. C. (2008). Economic deprivation, maternal depression, parenting and children's cognitive and emotional development in early childhood1. British Journal of Sociology, 59, 783-806.

King, V., \& Sobolewski, J. M. (2006). Nonresident fathers' contributions to adolescent well-being. Journal of Marriage and Family, 68, 537-557.

Lacey, R. E., Bartley, M., Pikhart, H., Stafford, M., \& Cable, N. (2014). Parental separation and adult psychological distress: An investigation of material and relational mechanisms. BMC Public Health, 14, 272.

Lane, K. L., Carter, E. W., Pierson, M. R., \& Glaeser, B. C. (2006). Academic, social, and behavioral characteristics of high school students with emotional disturbances or learning disabilities. Journal of Emotional and Behavioral Disorders, 14, 108-117.

Mayer, S. E. (1997). What money can't buy: Family income and children's life chances. Cambridge, MA: Harvard University Press.

McLanahan, S. (1997). Parent absence or poverty: Which matters more. In G. Duncan \& J. Brooks-Gunn (Eds.), Consequences of growing up poor (pp. 35-48). New York, NY: Russell Sage Foundation.

McLanahan, S., \& Booth, K. (1989). Mother-only families: Problems, prospects, and politics. Journal of Marriage and Family, 51, 557-580.

McLanahan, S., \& Sandefur, G. D. (1994). Growing up with a single parent: What hurts, what helps. Cambridge, MA: Harvard University Press.

McLanahan, S., Tach, L., \& Schneider, D. (2013). The causal effects of father absence. Annual Review of Sociology, 39, 399-427.

McLeod, J. D., \& Fettes, D. L. (2007). Trajectories of failure: The educational careers of children with mental health problems. American Journal of Sociology, 113, 653-701.

Morrison, D. R., \& Cherlin, A. J. (1995). The divorce process and young children's well-being: A prospective analysis. Journal of Marriage and Family, 57, 800-812.

Mortelmans, D., \& Jansen, M. (2010). Income dynamics after divorce: A latent growth model of income change on the European Community Household Panel. Brussels Economic Review, 53, 85-107.

Needham, B. L., Crosnoe, R., \& Muller, C. (2004). Academic failure in secondary school: The inter-related role of health problems and educational context. Social Problems, 51, 569-586.

Painter, G., \& Levine, D. I. (2004). Daddies, devotion, and dollars. How do they matter for youth? American Journal of Economics and Sociology, 63, 813-850.

Pedro-Carroll, J. (2011). How parents can help children cope with separation/divorce. In R. E. Tremblay, M. Boivin, \& R. D. Peters (Eds.), Encyclopedia on early childhood development. Montreal, Quebec: Centre of Excellence for 
Early Childhood Development.

Potter, D. (2010). Psychosocial well-being and the relationship between divorce and children's academic achievement. Journal of Marriage and Family, 72, 933-946.

Pryor, J., \& Rodgers, B. (2001). Children in changing families: Life after parental separation. Boston, MA: Wiley-Blackwell.

Rutter, M., Tizard, J., \& Whitmore, K. (1970). Education, health and behaviour. London, UK: Longman.

Sandefur, G. D., \& Wells, T. (1999). Does family structure really influence educational attainment? Social Science Research, 28, 331-357.

Saris, W. E., Satorra, A., \& van der Veld, W. M. (2009). Testing structural equation models or detection of misspecifications? Structural Equation Modeling, 16, 561-582.

Saris, W. E., van Wijk, T., \& Scherpenzeel, A. (1998). Validity and reliability of subjective social indicators: The effect of different measures of association. Social Indicators Research, 45, 173-199.

Sigle-Rushton, W., \& McLanahan, S. (2004). Father absence and child wellbeing: A critical review. In D. P. Moynihan, T. M. Smeeding, \& L. Rainwater (Eds.), The future of the family (pp. 116-159). New York, NY: Russell Sage Foundation.

Sigle-Rushton, W., Hobcraft, J., \& Kiernan, K. (2005). Parental divorce and subsequent disadvantage: A cross-cohort comparison. Demography, 42, 427-446.

Simons, R. L. \& Associates. (1996). Understanding differences between divorced and intact families: Stress, interaction, and child outcome. Thousand Oaks, CA: Sage Publications.

Simons, L. G., \& Conger, R. D. (2007). Linking mother-father differences in parenting to a typology of family parenting styles and adolescent outcomes. Journal of Family Issues, 28, 212-241.

Simons, R. L., Lin, K. H., Gordon, L. C., Conger, R. D., \& Lorenz, F. O. (1999). Explaining the higher incidence of adjustment problems among children of divorce compared with those in two-parent families. Journal of Marriage and Family, 61, 1020-1033.

Simons, R. L., Whitbeck, L. B., Beaman, J., \& Conger, R. D. (1994). The impact of mothers' parenting, involvement by nonresidential fathers, and parental conflict on the adjustment of adolescent children. Journal of Marriage and Family, 56, 356-374.

Thomson, E., Hanson, T. L., \& McLanahan, S. S. (1994). Family structure and child well-being: Economic resources vs. parental behaviors. Social Forces, 73, 221-242.

Van der Veld, W., Saris, W. E., \& Satorra, A. (2009). Jrule 2.0, Judgement aid rule for structural equation models: User manual. Retrieved from http://www.upf.edu/survey/working/extrafiles.html.

Velderman, M. K., Pannebakker, F. D., van Vliet, W., \& Reijneveld, S. A. (2016). Prevention of divorce-related problems in Dutch 4- to 8-year-olds cultural adaptation and pilot study of the children of divorce intervention program. Research on Social Work Practice. doi: 10.1177/1049731516644504.

Vélez, C., Wolchick, S. A., \& Sandler, I. N. (2011). Interventions to help parents and children through separation and divorce. In R. E. Tremblay, M. Boivin, \& R. D. Peters (Eds.), Encyclopedia on early childhood development. Montreal, Quebec: Centre of Excellence for Early Childhood Development.

Vitaro, F., Brendgen, M., Larose, S., \& Trembaly, R. E. (2005). Kindergarten disruptive behaviors, protective factors, and educational achievement by early adulthood. Journal of Educational Psychology, 97, 617-629.

Waters, E., Merrick, S., Treboux, D., Crowell, J., \& Albersheim, L. (2000). Attachment security in infancy and early adulthood: A twenty-year longitudinal study. Child Development, 71, 684-689.

Xu, A., Zhang, J., \& Xia, Y. R. (2008). Impacts of parents' divorce on chinese children: A model with academic performance as a mediator. Marriage and Family Review, 42, 91-119.

Wu, Z., Hou, F., \& Schimmele, C. M. (2008). Family structure and children's psychosocial outcomes. Journal of Family Issues, 29, 1600-1624. 


\section{Copyrights}

Copyright for this article is retained by the author(s), with first publication rights granted to the journal.

This is an open-access article distributed under the terms and conditions of the Creative Commons Attribution license (http://creativecommons.org/licenses/by/4.0/). 